\title{
PENGARUH SUHU DAN WAKTU PENYEDUHAN TEH HIJAU Sonneratia alba TERHADAP AKTIVITAS ANTIOKSIDANNYA
}

\author{
Bambang Budi Sasmito ${ }^{\mathrm{a}}$, Titik Dwi $\mathrm{S}^{\mathrm{a}}$, Dearta $\mathrm{D}^{\mathrm{a}}$ \\ ${ }^{\mathrm{a}}$ Fakultas Perikanan dan Ilmu Kelautan - UB \\ Jl. Veteran, Malang - Indonesia \\ *Koresponden penulis : niabbs@yahoo.com
}

\begin{abstract}
Abstrak
Teh hijau telah lama dipercaya memiliki kandungan antioksidan alami yang tinggi. Penelitian ini untuk memperoleh cara penyeduhan yang tepat dan identifikasi senyawa bioaktif sebagai antioksidan dalam teh hijau daun Sonneratia alba. Percobaan dirancang menggunakan Rancangan Acak Lengkap (RAL) faktorial dengan faktor suhu dan lama penyeduhan. Penyeduhan terbaik menggunakan suhu $100{ }^{\circ} \mathrm{C}$ selama 10 menit yang menghasilkan total tanin tertinggi sebesar 3,18\% dan nilai $\mathrm{IC}_{50}$ terhadap DPPH sebesar $96,5 \mathrm{ppm}$. Aktivitas antioksidan (FRAP) sebesar 105 ppm, kadar katekin 0,46\% dan total fenol 84,94 mgGAE/g. Teh hijau daun Sonneratia alba positif terhadap alkaloid, flavonoid, saponin, tanin. Senyawa bioaktif yang diduga sebagai antioksidan sebagian besar dari famili fenolik.
\end{abstract}

Kata kunci: antioksidan, polifenol, Sonneratia alba, tanin, teh hijau

\begin{abstract}
Green tea has long been believed to have high natural antioxidant content. This research is to obtain the right way of brewing and identification of bioactive compounds as antioxidants in Sonneratia alba green tea leaves. The experiment was designed using factorial completely randomized design (RAL) with temperature factor and duration of brewing. The best brewing uses a temperature of $100 \mathrm{oC}$ for 10 minutes which produces the highest total tannin of $3.18 \%$ and IC50 value of DPPH of $96.5 \mathrm{ppm}$. Antioxidant activity (FRAP) of $105 \mathrm{ppm}$, catechin levels $0.46 \%$ and total phenols $84.94 \mathrm{mgGAE} / \mathrm{g}$. Green tea leaves of Sonneratia alba are positive for alkaloids, flavonoids, saponins, tannins. Bioactive compounds that are suspected as antioxidants are mostly from the phenolic family.
\end{abstract}

Keywords: antioxidants, polyphenols, Sonneratia alba, tannins, green tea

\section{PENDAHULUAN}

Teh banyak dikonsumsi masyarakat sebagai minuman dan menempati urutan kedua setelah air. Teh dengan berbagai macam bentuk produk yang dapat dijumpai mulai dari produk minuman sampai suplemen makanan dengan berbagai kandungan senyawa bioaktif yang memilikinya. Berbagai fungsi senyawa bioaktif di dalam teh sebagai antikanker, antimikroba, menurunkan kolesterol darah, mengurangi gula darah, antibakterial dan yang populer adalah antioksidan. Teh hijau telah lama dikenal di China digunakan sebagai minuman sehat dan sering digunakan untuk pengobatan[1]. Sebagai sumber bioaktif khususnya senyawa antioksidan alami, teh hijau banyak digemari seiring semakin meningkatnya kesadaran masyarakat akan pentingnya senyawa antioksidan alami.

Keunggulan antioksidan alami selain kemampuannya menangkal radikal bebas, juga aman dalam pemanfaatannya. Kenyataan ini mendorong banyak peneliti, setidaknya dua atau tiga dekade terakhir banyak dilakukan eksplorasi antioksidan alami dari berbagai sumber seperti alga dan mangrove[2][3].

Teh hijau kaya senyawa katekin yang telah banyak diteliti sebagai agen antikanker. Katekin merupakan senyawa fenolik yang 
sangat kuat aktivitas antioksidannya. Bahkan sebagai prooksidan, senyawa ini dan derivatnya mampu menkelat beberapa logam yang menginduksi timbulnya stres oksidatif yang bertanggung jawab atas induksi apoptosis sel tumor[4].

Fenolik yang banyak terkandung dalam teh hijau sebagai antioksidan sangat rentan terhadap oksidasi. Penyeduhan yang tepat akan menghasilkan air teh seduhan yang kaya akan antioksidan. Kadangkala dijumpai penyeduhan semalaman untuk memperoleh minuman dari teh yang aroma dan warnanya menarik. Namun sering tidak disadari bahwa suhu dan waktu penyeduhan sangat menentukan mutu dan kandungan bioaktif yang terekstrak.

Masih banyak masyarakat yang kurang memperhatikan dan paham mengenai proses penyeduhan. Penelitian ini ditujukan untuk memperoleh suhu dan lama waktu penyeduhan daun teh hijau daun mangrove Sonneratia alba yang tepat.

\section{MATERIAL AND METHOD}

\section{Bahan Penelitian}

Bahan utama yang digunakan dalam penelitian ini adalah daun Sonneratia alba yang diperoleh dari Probolinggo. Bahanbahan lain yang digunakan dalam penelitian ini meliputi bahan pembuatan teh mangrove, seperti air, kantong teh dengan kualitas food grade, vitamin $\mathrm{C}$, metanol p.a, $\mathrm{FeCl}_{3}$, reagensia untuk uji fitokimia (Mayer; $\mathrm{Mg}$, $\mathrm{H}_{2} \mathrm{SO}_{4} 2 \mathrm{M}$, larutan $\mathrm{NaOH} 2 \mathrm{~N}$, larutan $\mathrm{HCl}$ $2 \mathrm{~N}$, asam galat dan 1,1-difenil-2-pikrilhidrazil (DPPH) serta bahan kimia untuk analisis laboratoris lainnya.

\section{Prosedur Penelitian}

Percobaan dirancang dengan Rancangan Acak Lengkap (RAL) faktorial dengan 3 kali ulangan. Faktor pertama yaitu variasi suhu penyeduhan $\left(70,85\right.$ dan $\left.100^{\circ} \mathrm{C}\right)$ dan faktor kedua adalah waktu penyeduhan yang terdiri tiga level yaitu 5, 10 dan 15 menit. Analisis data digunakan Anova yang dilanjutkan dengan BNT dengan taraf 5\%.

\section{Pembuatan Teh Hijau}

Daun segar Sonneratia alba diblanching dengan cara merebus daun dalam campuran abu sekam padi dan air (1:20; b/v) selama 30 menit pada suhu sekitar $80^{\circ} \mathrm{C}$. Selanjutnya di cuci dengan air hingga bersih dan terbebas dari sisa abu sekam, lalu direndam dengan air bersih $(1: 8 ; b / v)$ dengan pergantian air setiap 6 jam sekali selama 48 jam. Setelah perendam, dikeringkan menggunakan oven dengan suhu $70^{\circ} \mathrm{C}$ selama \pm 3 jam sampai sampel kering rapuh, dihancurkan dengan blender dan dikemas dalam kantong teh. Setiap kemasan berisi sekitar $\pm 2 \mathrm{~g}$ serbuk teh.

Setelah itu dilakukan proses penyeduhan dengan suhu $70^{\circ} \mathrm{C}(\mathrm{A} 1), 85^{\circ} \mathrm{C}$ (A2) dan $100^{\circ} \mathrm{C}$ (A3) selama 5 menit (B1), 10 menit (B2) dan 15 menit (B3). Selanjutnya dilakukan pengujian kandungan tanin, aktivitas antioksidan (DPPH) dan fitokimia. Hasil kombinasi perlakuan terpilih dilakukan pula uji total fenol dan identifikasi senyawa antioksidan dengan LCMS.

\section{Uji Kadar Tanin}

Kandungan tanin ditentukan menggunakan reagen Folin-Ciocalteu dan ditentukan secara spektrofotometri[5]. Sebanyak 0,1 ml ekstrak dalam labu ukur 10 $\mathrm{ml}$ ditambahkan ke 7,5 $\mathrm{ml}$ aquades, ditambahkan reagen Folin-Ciocalteu $0,5 \mathrm{ml}$ kemudian larutan $\mathrm{Na}_{2} \mathrm{CO}_{3} \quad 35 \% \quad \mathrm{~b} / \mathrm{v}$ ditambahkan hingga volumenya $10 \mathrm{ml}$. Setelah dinkubasi selama 30 menit, absorbansi diukur pada $\lambda 725 \mathrm{~nm}$. Sebagai larutan baku digunakan asam galat dan total tanin dinyatakan sebagai mgGAE/g sampel.

\section{Uji Aktivitas Antioksidan dengan DPPH}

Aktivitas antioksidan diuji dengan reagen 1,1-difenil-2-pikrilhidrazil[6]. Sebanyak $1 \mathrm{~mL}$ ekstrak metanol dari teh hijau dengan konsentrasi $50 \mu \mathrm{g} / \mathrm{mL}$. $75 \mu \mathrm{g} / \mathrm{mL}, 100 \mu \mathrm{g} / \mathrm{mL}$, $125 \mu \mathrm{g} / \mathrm{mL}$ dan $150 \mu \mathrm{g} / \mathrm{mL}$ ditambahkan kedalam $2 \mathrm{~mL}$ DPPH 0,1 mM. Campuran selanjutnya dikocok dan diinkubasi pada suhu kamar selama 30 menit ditempat gelap. Larutan ini selanjutnya diukur absorbansinya pada $\lambda 516 \mathrm{~nm}$.

\section{Uji Total Fenolat}

Total fenol seduhan teh hijau Sonneratia alba ditentukan dengan menggunakan reagen Folin-Ciocalteu[7]. Pengujian total polifenol hanya dilakukan pada air seduhan yang terkuat aktivitas antioksidannya. $250 \mu \mathrm{l}$ masing-masing sampel dicampur dengan 
$1250 \mu \mathrm{l}$ aquadest, $250 \mu \mathrm{l}$ etanol dan $125 \mu \mathrm{l}$ reagen Folin-Ciocalteu. Selanjutnya diinkubasi pada suhu kamar selama 5 menit dan kemudian ditambahkan $250 \mu \mathrm{l}$ larutan natrium karbonat 5\%. Campuran dibiarkan selama 60 menit dalam ruang gelap pada suhu kamar. Absorbansi masing-masing sampel diukur dengan spektrofotometer pada $\lambda 725 \mathrm{~nm}$. Total kandungan fenolat dinyatakan sebagai mgGAE/g sampel berdasarkan kurva baku asam galat.

\section{Uji Aktivitas Antioksidan dengan FRAP}

Kekuatan senyawa antioksidan dalam ekstrak etanol teh hijau daun S. alba mereduksi Ferric ditentukan dengan metode yang telah digunakan[8]. Setelah menyiapkan larutan sampel, 0,15 $\mathrm{ml}$ larutan standar dan ekstrak diambil untuk direaksikan dengan larutan FRAP $(2,85 \mathrm{ml})$ dalam kondisi gelap. Setelah 30 menit, absorbansi diamati pada $\lambda$ $593 \mathrm{~nm}$.

\section{Uji Fitokimia}

Uji fitokimia ekstrak teh hijau meliputi alkaloid, flavonoid, saponin dan tannin[9]. Adapun pengujian masing-masing parameter tersebut sebagai berikut:

Alkaloid: $0,1 \mathrm{mg}$ ekstrak teh hijau Sonneratia alba (sampel) dilarutkan dalam $10 \mathrm{ml}$ kloroform, ditambah 3 tetes $\mathrm{NH}_{4} \mathrm{OH}$ kemudian dikocok dan disaring. Filtrat dipindahkan ke tabung reaksi, ditambah beberapa tetes $\mathrm{H}_{2} \mathrm{SO}_{4} 2 \mathrm{M}$, selanjutnya larutan asam ditambahkan 1 tetes pereaksi Mayer. Endapan putih kekuningan yang terbentuk menunjukkan kehadiran senyawa alkaloid.

Flavonoid: $1 \mathrm{ml}$ sampel dalam tabung reaksi ditambahkan $0,05 \mathrm{~g}$ serbuk $\mathrm{Mg}$, ditambahkan $1 \mathrm{ml}$ HCL dan $1 \mathrm{ml}$ amilalkohol dikocok dibiarkan beberapa saat. Kehadiran senyawa flavonoid diindikasikan terbentuknya warna kuning sampai jingga.

Saponin: sebanyak $0,1 \mathrm{mg}$ sampel ditambah $10 \mathrm{ml}$ aquades lalu dididihkan selama 2 sampai 3 menit, setelah dingin dikocok dan didiamkan sesaat. Terbentuknya buih yang stabil saat ditambahkan 1 tetes HCL menunjukkan adanya saponin.

Tanin: sebanyak $0.1 \mathrm{mg}$ sampel ditambah $10 \mathrm{ml}$ aquadest lalu dididihkan, selanjutnya disaring dan filtratnya ditambah larutan $\mathrm{FeCl}_{3} 1 \%$, terbentuknya warna hijau kehitaman sebagai indikator positif mengandung tanin.

Identifikasi Senyawa Antioksidan (LCMS)

Pendugaan senyawa bioaktif dalam sampel dengan penentuan bobot massa senyawa menggunakan LC-MS, Licuid Chromatography-Mass Spectroscopy (Instrumen HPLC-MS ESI, Electrospray Ionization) mode ion positif. Spektrum massa senyawa dianalisis menggunakan Masslynx software untuk mendapatkan rumus molekul (senyawa dan massa relatifnya), selanjutnya penentuan senyawa dikonfirmasi dengan data base pada Chemspider dan Massbank.

\section{HASIL DAN PEMBAHASAN}

\section{Total Tanin}

Kandungan tanin seduhan teh hijau bervariasi dari $1,29 \pm 0,06 \%$ sampai dengan $3,18 \pm 0,17 \%$. Hasil analisis statistika menunjukkan bahwa suhu dan lama penyeduhan sangat berpengaruh terhadap kandungan tanin seduhannya $(\mathrm{P}<0.01)$. Total tanin masing-masing pengaruh kombinasi perlakuan suhu dan lama penyeduhan seperti terlihat pada Gambar 1.

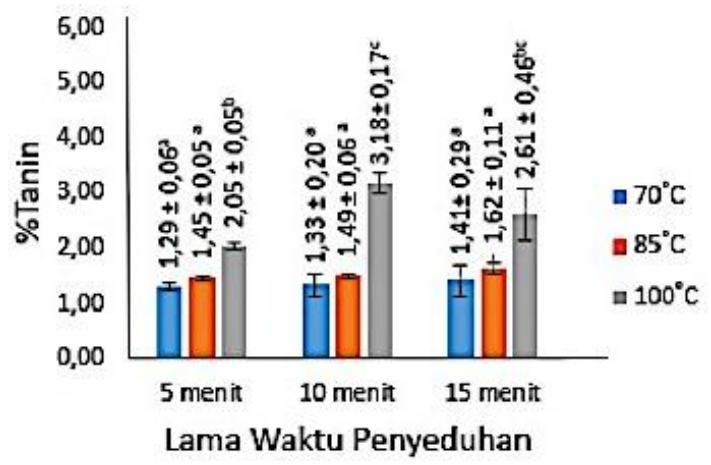

Gambar 1. Total tanin seduhan teh hijau S. alba

Kandungan tanin dalam teh sangatlah bervariasi, dan sangat tergantung dari jenis teh, cara proses dan faktor lainnya seperti bahan bakunya. Selain itu cara penyajian termasuk suhu dan waktu penyeduhan sangat berpengaruh terhadap kandungan tanin air teh seduhannya. Penyeduhan selama 10 menit dengan suhu awal $100^{\circ} \mathrm{C}$ menghasilkan air seduhan teh hijau yang tertinggi kandungan taninnya. Seiring lamanya waktu seduh akan memungkinkan lebih banyak tanin terdifusi dari dalam teh keluar (terekstrak) sehingga konsenrasi tanin meningkat dalam air seduhannya. Demikian 
pula dengan semakin tinggi suhu air penyeduh sebagai pelarut menyebabkan semakin cepat terjadinya ekstraksi tanin. Tanin terutama yang terkondensasi akan mengalami degradasi akibat suhu[10], sehingga semakin lama penyeduhan pada suhu tinggi bisa mengakibatkan penurunan kandungan tanin. Pada Gambar 1 terlihat bahwa kandungan tanin dalam air seduhan teh hijau dengan suhu tertinggi selama 15 menit lebih rendah kandungannya dibanding penyeduhan pada suhu selama10 menit.

\section{Aktivitas Antioksidan ( IC $\left._{50}\right)$}

Nilai $\mathrm{IC}_{50}$ terhadap DHHP seduhan teh hijau bervariasi dari $96,5 \pm 0,53 \mathrm{ppm}$ sampai

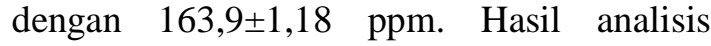
statistika menunjukkan bahwa suhu dan lama penyeduhan sangat berpengaruh terhadap aktivitas antioksidan seduhannya $(\mathrm{P}<0.01)$. Rerata nilai $\mathrm{IC}_{50}$ seduhan teh hijau daun $S$. alba pengaruh kombinasi perlakuan suhu dan lama penyeduhan seperti terlihat pada Gambar 2.

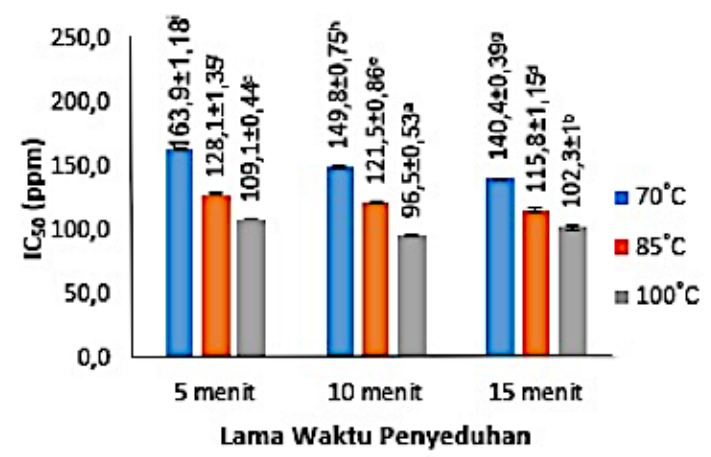

Gambar 2. Nilai IC $_{50}$ terhadap DPPH

Aktivitas antioksidan yang diukur dari daya tangkalnya terhadap radikal bebas diekspresikan dengan nilai inhibitory concentration $\left(\mathrm{IC}_{50}\right)$. Pada Gambar 2 terlihat bahwa nilai $\mathrm{IC}_{50}$ terendah ditunjukkan hasil seduhan dengan suhu $100^{\circ} \mathrm{C}$ selama 10 menit. Hal ini menunjukkan bahwa air seduhan teh hijau tersebut memiliki aktivitas antioksidan paling tinggi didanding hasil perlakuan lainnya. Hal ini diduga karena kandungan polifenol yang terekstrak dalam air teh hijau dari perlakuan tersebut paling tinggi (kadar katekin $0,46 \%$ dan total fenol $84,94 \pm 1,647 \quad \mathrm{mgGAE} / \mathrm{g})$. Katekin merupakan kelompok antioksidan alami yang sangat kuat dan banyak terdapat dalam teh hijau[10][11]. Namun demikian sebagai antioksidan juga sangat rentan dan mudah mengalami degradasi, sehingga penyeduhan yang terlalu lama juga dapat menurunkan kandungannya dalam air seduhan.

\section{Fitokimia}

Hasil pengujian fitokimia air seduhan teh hijau daun $S$. alba disajikan pada Tabel 1 berikut.

Tabel 1. Hasil Uji Fitokimia Teh Hijau S. alba

\begin{tabular}{lcccc}
\hline \multirow{2}{*}{ Sampel } & \multicolumn{5}{c}{ Fitokimia } \\
\cline { 2 - 5 } & Alkaloid & Flavonoid & Saponin & Tanin \\
\hline A1B1 & + & + & + & + \\
\hline A1B2 & + & + & + & + \\
\hline A1B3 & + & + & + & + \\
\hline A2B1 & + & + & + & + \\
\hline A2B2 & + & ++ & + & ++ \\
\hline A2B3 & + & ++ & + & +++ \\
\hline A3B1 & + & ++ & + & ++ \\
\hline A3B2 & + & +++ & + & +++ \\
\hline A3B3 & + & ++ & + & +++ \\
\hline
\end{tabular}

Keterangan: Intensitas (+ rendah, ++ sedang, +++ tinggi)

Dari hasil uji fitokimia (Tabel 1) dapat dilihat bahwa semua air seduhan teh hijau $S$. alba positif mengandung senyawa alkaloid, flavonoid, saponin dan tanin. Namun demikian dilihat dari intensitasnya ada beberapa perbedaan terutama pada uji flavonoid dan tanin. Perlakuan A3B2 memberikan indikasi paling tinggi kandungan flavonoid dan tanin. Kenyataan ini sejalan dengan hasil analisis aktivitas antioksidannya, dimana seduhan dari perlakuan tersebut memiliki nilai $\mathrm{IC}_{50}$ terendah; atau aktivitas antioksidannya tertinggi.

\section{Senyawa Antioksidan dan Total Fenol}

Senyawa bioaktif yang diduga memiliki aktivitas antioksidan didominasi famili polifenol utamanya dari flavonoid, dan hanya sebagian kecil dari kelompok non flavonoid. Hasil analisis total fenol hasil perlakuan A3B2 adalah sebesar 84,94 $\pm 1,647 \mathrm{mgGAE} / \mathrm{g}$. Selanjutnya hasil analisis identifikasi senyawa antioksidan menggunakan HPLCESI-MS mode positif disajikan pada Gambar 3. Selanjutnya hasil identifikasi menunjukkan bahwa dalam teh hijau daun $S$. alba setidaknya mengandung 11 senyawa 
yang diduga memiliki aktivitas antioksidan; selengkapnya dapat dilihat Tabel 2.

Tabel 2. Senyawa Antioksidan Teh Hijau S. alba

\begin{tabular}{ll}
\hline Parameter & $\mathbf{R m}^{\mathrm{a}} ; \mathbf{M}_{\mathbf{s}} \mathbf{m}(\mathbf{D a})^{\mathrm{b}}$ \\
\hline $\begin{array}{l}\text { 6,7-Dimethoxy-4-methyl- } \\
\text { coumarin, }\end{array}$ & $\mathrm{C}_{12} \mathrm{H}_{12} \mathrm{O}_{4} ; 220.221$ \\
\hline 2'-Hydroxy-a-naphtho-flavone & $\mathrm{C}_{19} \mathrm{H}_{12} \mathrm{O}_{3} ; 288.297$ \\
\hline Epicatechin, & $\mathrm{C}_{15} \mathrm{H}_{14} \mathrm{O}_{6} ; 290.268$ \\
\hline Luteolin-7-O-glucoside, & $\mathrm{C}_{21} \mathrm{H}_{20} \mathrm{O}_{11} ; 448.377$ \\
\hline Cyanidin-3-glucoside, & $\mathrm{C}_{21} \mathrm{H}_{21} \mathrm{O}_{11} ; 449.384$ \\
\hline Kaemferol, & $\mathrm{C}_{15} \mathrm{H}_{10} \mathrm{O}_{6} ; 286.236$ \\
\hline Ellagic acid, & $\mathrm{C}_{14} \mathrm{H}_{6} \mathrm{O}_{8} ; 302.193$ \\
\hline Laevopimaric acid, & $\mathrm{C}_{20} \mathrm{H}_{30} \mathrm{O}_{2} ; 302.451$ \\
\hline Quercetin, & $\mathrm{C}_{15} \mathrm{H}_{12} \mathrm{O}_{8} ; 320.251$ \\
\hline Caffein, & $\mathrm{C}_{8} \mathrm{H}_{10} \mathrm{~N}_{4} \mathrm{O}_{2} ;$ \\
\hline Liquiritigenin & 194.191 \\
\hline & $\mathrm{C}_{15} \mathrm{H}_{12} \mathrm{O}_{4} ; 256.253$ \\
\hline
\end{tabular}

Keterangan: ${ }^{\mathrm{a}}$ Rumus Molekul, ${ }^{\mathrm{b}}$ Massa Molekul (Dalton)

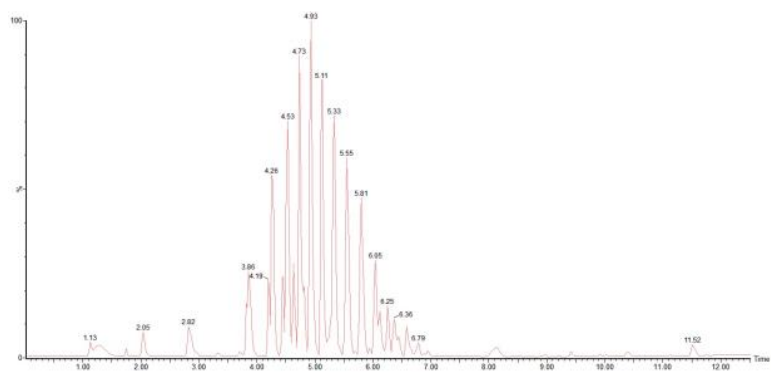

Gambar 3. Kromatogram Senyawa Antioksidan

Pada Gambar 3 dapat dilihat lebih dari 11 puncak yang menunjukkan senyawa yang terdeteksi. Namun demikian hanya sebelas senyawa yang terkonfirmasi sebagai bioaktif yang diduga sebagai antioksidan alami. Senyawa-senyawa tersebut adalah sebagai berikut:

6,7-Dimethoxy-4-methylcoumarin, senyawa derivat coumarin dan memiliki aktivitas antioksidan cukup tinggi [12]. Caoumarin sebagai metabolit sekunder banyak disintesis oleh tanaman. Selain memiliki aktivitas sebagai antioksidan, juga beberapa derivatnya digunakan sebagai antiinflamasi, antimikrobial dan sejenisnya [13].

2'-Hydroxy-a-naphtho-flavone, polifenol non flavonoid ini tergolong senyawa antioksidan. Selain itu senyawa ini juga memiliki potensi antiinflamatori atau peradangan[14].

Luteolin-7-O-glucoside, dan Cyanidin3-glucoside senyawa fenolat yang selain ditemukan dalam ekstrak teh hijau juga banyak terdapat dalam daun tumbuhan lain. Seperti dilaporkan bahwa ekstrak daun Olea juga terdapat senyawa antioksidan ini[15].

Kaemferol atau $\quad(3,4,5,7-$ tetrahydroxyflavone), flavonol alami yang termasuk flavonoid dengan aktivitas biologis sebagai antioksidan, antimikrobial dan aktivitas biologis lainnya [16].

Banyak derivat kaemferol yang diekstrak dari tumbuhan dan memiliki kemampuan menangkap radikal bebas (DPPH) secara baik. Seperti dilaporkan Ferreres[17], bahwa ekstrak dengan air panas daun bagian dalam kobis mengandung senyawa antioksidan yang cukup tinggi.

Ellagic acid, merupakan senyawa antiokisdan, termasuk kelompok tanin. Selain sebagai senyawa antioksidan juga mempunyai aktivitas biologis sebagai penghambat terjadinya alzheimer dan antidiabetik[18][19].

Epicatechin, salah satu senyawa fenolik yang memiliki aktivitas antioksidan. Senyawa ini banyak terdapat dalam tumbuhan dan terdistribusi secara luas. Pada umumnya daun teh juga banyak mengandung senyawa fenolik ini[11].

Quercetin, merupakan flavonoid yang sangat kuat aktivitas antioksidannya[20] dan paling menonjol dikelompoknya[21]

Liquiritigenin derivat flavonoid yang mungkin juga memiliki aktivitas antioksidan dan belum ada informasi fungsi biologisnya[22][23][24].

\section{KESIMPULAN}

Air seduhan teh hijau Sonneratia alba pada suhu $100^{\circ} \mathrm{C}$ selama 10 menit mengandung senyawa polifenol termasuk tanin dan memiliki aktivitas cukup tinggi, yaitu nilai $\mathrm{IC}_{50}$ terhadap DPPH sebesar 96,5 ppm, nilai FRAP sebesar 105 ppm, dan total fenol 84,94 mgGAE/g.

\section{UCAPAN TERIMAKASIH}

Terima kasih kepada teman-teman peneliti bioaktif dari mangrove: Astuti, 
Tamara dan lainnya yang telah membantu kami. Semoga kalian semua sukses, optimistis dan tetap semangat.

\section{DAFTAR PUSTAKA}

[1] C. Cabrera, R. Artacho, and R. Giménez, "Beneficial Effects of Green Tea-A Review," J. Am. Coll. Nutr., vol. 25, no. 2, pp. 79-99, Apr. 2006.

[2] B. B. Sasmito, S. Kumalaningsih, and W. Susinggih, "Effect of Crystallization and Maceration Time on Antioxidant Activity of Ethanolic Extract from Brown Algae Sargassum sp," vol. 2, no. 2, pp. 861-867, 2014.

[3] Hardoko, B. B. Sasmito, Y. E. Puspitasari, Y. D. Okviani, and Y. Halim, "The effect of heating temperature on inhibitory activity of mangrove rhizophora mucronata fruit extract toward A-glucosidase," Asian J. Pharm. Clin. Res., vol. 11, no. 7, pp. 237-241, 2018.

[4] J. D. Lambert and R. J. Elias, "The antioxidant and pro-oxidant activities of green tea polyphenols: A role in cancer prevention," Arch. Biochem. Biophys., vol. 501, no. 1, pp. 65-72, 2010.

[5] E. L. C. Amorim, J. E. Nascimento, J. M. Monteiro, T. J. S. P. Sobrinho, T. A. S. Araújo, and U. P. Albuquerque, "A simple and accurate procedure for the determination of tannin and flavonoid levels and some applications in ethnobotany and ethnopharmacology," Funct. Ecosyst. Communities, vol. 2, no. 1, pp. 88-94, 2008.

[6] P. Molyneux, "The use of the stable free radical diphenylpicryl-hydrazyl (DPPH) for estimating anti-oxidant activity," Songklanakarin J. Sci. Technol., vol. 26, no. May, pp. 211219, 2004.

[7] S. F. Chandler and J. H. Dodds, "The effect of phosphate, nitrogen and sucrose on the production of phenolics and solasodine in callus cultures of solanum laciniatum," Plant Cell Rep., vol. 2, no. 4, pp. 205-208, 1983.

[8] J. Jaslin Edward and V. Padmaja, "In vitro antioxidant activity of ethanolic extract of aerial parts of Coleus spicatus. Benth," Asian J. Chem., vol. 23, no. 11, pp. 5099-5101, 2011.

[9] J. B. Harborne, Phytochemical Methods: A Guide to Modern Techniques of Plant Analysis. second ed., Chapman and Hall, New York, USA. 1984.

[10] N. Powell, Green tea and health: Antioxidant properties, consumption and role in disease prevention. 2015.

[11] H. Zhang, B. Tang, and K. Row, "Extraction of catechin compounds from green tea with a new green solvent," Chem. Res. Chinese Univ., vol. 30, no. 1, pp. 37-41, 2014.

[12] T. K. Lim, "Tagetes lucida BT Edible Medicinal And Non-Medicinal Plants: Volume 7, Flowers," T. K. Lim, Ed. Dordrecht: Springer Netherlands, 2014, pp. 448-455.

[13] K. Kim et al., "Original article: ProInflamatory Mediator Expression Through Inactivation of The NF- $\square$ B and Mapk Pathways IN," no. Dmc, pp. 792-800, 2014.

[14] C. C. Vasconcelos, A. Jorge, O. Lopes, and E. Lucas, "Effects of Extract of Arrabidaea chica Verlot on an Experimental Model of Osteoarthritis," Int. J. Mol. Sci. 2019, 20, 4717, 2019.

[15] A. Romani, A. Scardigli, and P. Pinelli, "An environmentally friendly process for the production of extracts rich in phenolic antioxidants from Olea europaea L. and Cynara scolymus L. matrices," Eur. Food Res. Technol., vol. 243, no. 7, pp. 1229-1238, 2017.

[16] S. J. N. Tatsimo et al., "Antimicrobial and antioxidant activity of kaempferol 
rhamnoside derivatives from Bryophyllum pinnatum," BMC Res. Notes, vol. 5, no. 1, p. 158, 2012.

[17] F. Ferreres et al., "Chemical composition and antioxidant activity of tronchuda cabbage internal leaves," Eur. Food Res. Technol., vol. 222, no. 1, pp. 88-98, 2006.

[18] Z. Kiasalari et al., "Ellagic acid ameliorates learning and memory deficits in a rat model of Alzheimer's disease: an exploration of underlying mechanisms," Psychopharmacology (Berl)., vol. 234, no. 12, pp. 18411852, 2017.

[19] N. Fatima, R. M. Hafizur, A. Hameed, S. Ahmed, M. Nisar, and N. Kabir, "Ellagic acid in Emblica officinalis exerts anti-diabetic activity through the action on $\beta$-cells of pancreas," Eur. $J$. Nutr., vol. 56, no. 2, pp. 591-601, 2017.

[20] J. V Formica and W. Regelson, "Review of the biology of quercetin and related bioflavonoids," Food Chem. Toxicol., vol. 33, no. 12, pp. 1061-1080, 1995.

[21] A. W. Boots, G. R. M. M. Haenen, and A. Bast, "Health effects of quercetin: From antioxidant to nutraceutical," Eur. J. Pharmacol., vol. 585, no. 2, pp. 325-337, 2008.

[22] J. E. Cooper, J. R. Rao, E. Everaert, and L. De Cooman, "Metabolism of Flavonoids by Rhizobia BT - Nitrogen Fixation: Fundamentals and Applications: Proceedings of the 10th International Congress on Nitrogen Fixation, St. Petersburg, Russia, May 28-June 3, 1995," I. A. Tikhonovich, N. A. Provorov, V. I. Romanov, and W. E. Newton, Eds. Dordrecht: Springer Netherlands, 1995, pp. 287-292.

[23] P.-G. Pietta, "Flavonoids as Antioxidants," J. Nat. Prod., vol. 63, no. 7, pp. 1035-1042, Jul. 2000.

[24] A. Wang, Y. Lu, P. Shi, and H. Zhang,
"Hydroxyl and hydroperoxyl radicals scavenging by isoliquiritigenin and liquiritigenin: a quantum chemical study," Struct. Chem., vol. 28, no. 4, pp. 1181-1186, 2017. 